\title{
Producing Expertise in a Transitional Justice Setting: Judges at Rwanda's Gacaca Courts
}

\author{
Hollie Nyseth Brehm, Christi Smith, and Evelyn Gertz
}

In the aftermath of the 1994 Genocide Against the Tutsi, the Government of Rwanda created courts to hold hundreds of thousands of suspected génocidaires accountable. Faced with an unprecedented volume of cases, each community elected lay judges known as inyangamugayo to preside over the court proceedings. With no prior legal training, these individuals held trials for a decade, levying sentences ranging from minor fines to life in prison. This article draws from forty-six interviews with former inyangamugayo to make two primary contributions. First, we examine how professional boundaries shifted during a period of upheaval such that laypeople performed tasks typically undertaken by professionals. Second, we highlight the centrality of social capital-and, more specifically, reputations - in the inyangamugayo's election and tasks. In doing so, we illustrate how the inyangamugayo leveraged their reputations to secure the cooperation of fellow community members in adjudicating crimes of genocide.

\section{INTRODUCTION}

The 1994 Genocide Against the Tutsi left Rwanda and its institutions in shambles. In the aftermath, the new government sought to hold hundreds of thousands of Rwandan civilians accountable for the violence. As the existing justice system was not capable of processing this immense caseload, the government created local courts that were staffed by lay members of the community known as inyangamugayo ("people of integrity"). Although these individuals had no prior legal training and were not paid, they carried out tasks previously assigned to professionals to accomplish the urgent need of adjudicating crimes of genocide for their crimes. The

Hollie Nyseth Brehm is an Assistant Professor of Sociology at The Ohio State University and may be contacted at brehm.84@osu.edu.

Christi M. Smith is Assistant Dean and Senior Scholar at the Washington University of Saint Louis' Center for Diversity and Inclusion. Her research focus is in comparative higher education policy.

Evelyn Gertz is a PhD candidate in Sociology at The Ohio State University and a National Science Foundation Graduate Research Fellow. Her research interests include ethnic identity, violence, religion, and emotion. She has conducted quantitative and qualitative fieldwork on these topics in Rwanda and Israel.

Professor Nyseth Brehm's work on this project was funded by the National Science Foundation (Award Number 1626123), the Mershon Center for International Security Studies, and the American Sociological Association Fund for the Advancement of the Discipline. This project was approved by The Ohio State University Social and Behavioral Sciences Institutional Review Board, and she thanks Christopher Uggen and Jean-Damascène Gasanabo for important assistance on the broader project. 
majority of the inyangamugayo worked numerous hours every week for a decade, collectively presiding over 1.96 million trials across Rwanda (Nyseth Brehm, Uggen, and Gasanabo 2014).

This article relies on interviews with forty-six inyangamugayo to make two primary contributions. First, we highlight how the familiar processes that determine who performs professional work-such as the acquisition of formal credentialswere upended during a period of transitional justice. Instead, laymen and women presided over trials for genocide and completed tasks that are typically performed by those with some formal training. Our case study consequently accords with Eyal's (2013, 871) call for an expanded consideration of the social processes through which various actors, both credentialed and non-credentialed, contribute to the "speedy and superior execution of a task." Second, we illuminate some of the mechanisms that enabled laypeople to undertake their work in these courts, illustrating that social capital served as the requisite credential for their election and subse-

quent work. A primary component of the inyangamugayo's social capital was their reputation as upstanding members of their communities, and they accordingly sought to protect their reputations through public demonstrations of integrity, including policing potential corruption on their benches. The inyangamugayo likewise relied heavily on broader social networks to accomplish their tasks, further illustrating the importance of social capital in this context.

We begin with an overview of professions and the work of professionals in transitional justice settings, examining how a critical juncture can shift the boundaries around who performs professional tasks. Next, we briefly discuss the case of Rwanda's post-genocide gacaca courts, followed by a summary of our interviews with forty-six inyangamugayo. We then demonstrate how laypeople presided over their fellow citizens' cases of genocide and thereby performed vital work in the aftermath of mass violence. Finally, we conclude by suggesting that reputations and social networks may take on an increased salience in the absence of formal credentialing processes.

\section{PROFESSIONS AND TRANSITIONAL JUSTICE}

Judgeships are professions, which sociologists have conceptualized as distinct from other occupations due to their autonomy over a field of work, the strong associations that protect entrée to and status of membership, and the authority to regulate and discipline professional members (Larson 1977; Abbott 1988; Bourdieu 1996). A robust body of scholarship has accordingly theorized professions as bounded categories whereby credentialed actors control their jurisdiction through boundary-making processes. To date, however, this work has overwhelmingly focused on professions in the United States and Western Europe (Faulconbridge and Muzio 2012; Kuhlmann 2013; Liu 2017). Scholarship on legal professions has likewise suffered from a Western bias, and scholars have recently suggested that jurisdictional studies of judges and related legal professions should transcend their limited focus on Western case studies (Michelson 2006, 2007; Liu 2013). 
This article heeds these calls by examining the performance of legal work during a transitional justice process, ${ }^{1}$ or the process by which a country transitions from mass violence or widespread human rights violations to a time of relative peace (Osiel 1997; Teitel 2000). The term "transitional justice" initially referred to the legal strategies that national and international actors implemented to aid countries as they transitioned to democracy (Kritz 1995). In recent decades, transitional justice has come to include the judicial and non-judicial mechanisms employed to respond to violent or repressive pasts (Kritz 1995; Roht-Arriaza and Mariezcurrena 2006; Sikkink 2011). ${ }^{2}$ These transitional justice efforts are expansive and often involve numerous pursuits, such as truth and reconciliation commissions, memorials, reparations, and-most pertinent to our case-trials.

As transitional justice efforts have proliferated, international organizations have often orchestrated the proceedings (Teitel 2003). Scholars have accordingly examined the role of professionals in international tribunals and other international endeavors (Lefranc and Vairel 2014). These professionals include the lawyers, judges, and other legal personnel who staff international tribunals (e.g., Hagan 2003; Garbett 2012) as well as the international actors who have become transitional justice experts and entrepreneurs, such as representatives of international governmental organizations and human rights activists (e.g., Madlingozi 2010).

Transitional justice endeavors have also been localized ${ }^{3}$ in the sense that local actors and organizations have been instrumental in creating, orchestrating, and assessing courts, truth commissions, and related mechanisms. In fact, many scholars lament the international legalization of transitional justice and have suggested that individuals residing where the violence or repression occurred should play a more prominent role (McEvoy 2007; Shaw, Waldorf, and Hazan 2010). However, the precise local actors who play this role tend to vary. In many cases, credentialed and licensed professionals spearhead local transitional justice efforts. Bosnia and Herzegovina's hybrid war crimes chamber, for instance, employed numerous licensed Bosnian judges and prosecutors (Ivanisevic 2008), while local Iraqi judges participated in post-2003 transitional justice efforts (Stover, Megally, and Mufti 2005). In other settings, nonprofessionals play key roles in the transitional justice process. For example, community elders led Uganda's mato oput rituals in the wake of violence committed by the Lord's Resistance Army (Baines 2007), meaning that individuals with no formal conflict resolution training or legal credentials were responsible for determining compensation paid to victims and/or their families. ${ }^{4}$ In much the same way, members of civil society played core roles in shaping and implementing transitional justice mechanisms in East Timor, Peru, Sierra Leone, and Ghana (Gready and Robins 2010).

1. Other scholarship has examined the daily work of lawyers or judges during periods of upheaval (McEvoy 2011; see also Ellman 1995; Cheh 2005).

2. The 1990s saw a sharp increase in prosecutions for human rights violations (Sikkink 2011), while countries that had been mired in Cold War proxy wars struggled to address their pasts in the pursuit of stability (Kritz 1995; Teitel 2000).

3. See Nyseth Brehm and Golden (2017) for more on "local" transitional justice.

4. Mato oput was arguably a community reconciliation tool rather than a legal one, though elders wielded power over the process, including compensation outcomes. 
This article examines another case in which lay members of the community were prominently involved in a transitional justice process. Judges in Rwanda's gacaca courts had little legal training to guide them as they adjudicated difficult, legally binding cases of genocide. The gacaca courts consequently offer an important opportunity to analyze laypeople's roles in transitional justice efforts and, specifically, the factors that enabled laypeople to take on these roles and carry out the associated tasks. Before addressing this, however, we examine why laypeople came to adjudicate crimes of genocide and suggest that the sociology of expertise provides an appropriate lens through which to theorize their efforts.

\section{CRITICAL JUNCTURES AND EXPERTISE}

Although it may seem surprising that laypeople stepped into roles as judges in the aftermath of a genocide, the phenomenon of shifting institutional arrangements post-violence is not new. Rather, the shift stems (at least in part) from the transformative potential of mass violence. Often referred to as a "critical juncture," mass violence is period of significant change that reflects a discontinuation of the status quo and the possibility for new social processes and institutional arrangements (Mahoney 2000; Pierson 2004; Mann 2013). Perhaps most broadly, Tilly (1985, 170) argued that "wars make states," while Weber ([1922] 1978) suggested that the development of bureaucratic rationality within militaries significantly affected modern state institutions. Mass violence has likewise influenced the emergence of revolutions (e.g., Moore 1966; Tilly 1978; Skocpol 1979), welfare state and civic organization formation (e.g., Skocpol 1992), citizenship rights (e.g., Markoff 1996; Kestnbaum 2002), and women's political participation (e.g., Hughes and Tripp 2015; Berry 2018).

In the case of Rwanda, a critical juncture influenced an urgent need to try those suspected of participating in the genocide, which in turn took precedence over the desire to entrust only credentialed professionals with the duties of the judiciary. Specifically, due to the widespread death and displacement caused by the genocide, there were only twelve prosecutors and 244 judges in Rwanda, compared to the seventy prosecutors and 758 judges in the country before 1994 (Gacaca Report Summary 2012). The boundaries around certain professional tasks necessarily shifted to allow for laypeople to perform essential tasks.

To be certain, lay individuals perform legal work in other contexts. England's lay magistrates (Diamond 1990), for instance, have wielded substantial sentencing power, and some argue that such participatory practices offer an important intervention to the increasingly harsh criminalization of many capitalist states (Bond and Lemon 1981; Johnstone 2000). Likewise, US-focused scholarship suggests that noncredentialed actors can play meaningful roles representing clients during civil trials. For instance, Carpenter, Mark, and Shanahan (2016) found that experienced nonlawyer advocates can help parties with common court procedures. ${ }^{5}$ Further, police in many societies make discretionary decisions every day as to whether to invoke

5. Notably, networks of other court actors played a crucial role helping these non-experts develop legal expertise (Carpenter, Mark, and Shanahan 2016). 
the law, substantially impacting the administration of criminal justice and thus the judicial profession (Green 1997).

Before the genocide in Rwanda, however, individuals who had been trained and licensed presided over serious crimes (like homicide) in formal court systems. Although the gacaca courts were partially rooted in past practices, as we further describe below, they nonetheless represented a large departure from how Rwanda had previously handled serious crime. In this case, the social processes and shifting institutional arrangements that often stem from mass violence also extended to legal work. Although the gacaca court judges were clearly not professionals, they were tasked with prosecuting crimes of genocide and facilitating the reconciliation of a devastated nation, due in large part to the lack of trained legal professionals.

In line with this, Eyal (2013) articulates how many people-both skilled and unskilled-contribute to identifying problems and implementing solutions, which he calls constructing "expertise." Through his demonstration of how therapists, psychologists, and parents of children with autism influenced the rise of autism diagnoses in the United States, Eyal argues that laypeople can play an important role in addressing issues that often fall under the jurisdiction of professionals. He thus suggests that the sociology of professions needs to expand such that it includes individuals who are not credentialed professionals, but who nonetheless respond to pressing tasks and problems, regardless of the actual knowledge or skills they bring to such tasks.

Indeed, contributing to expertise does not make one an "expert." Rather, Eyal (2013, 869) highlights an important analytical distinction "between, on the one hand, the actors who make claims to jurisdiction over a task by 'professing' their disinterest, skill, and credibility and, on the other hand, the sheer capacity to accomplish this task better and faster." Rather than viewing expertise as a quality of professionals, this approach emphasizes the broader symbolic and material resources, concepts, and social arrangements necessary to accomplish tasks, conceptualizing expertise as networks that "link together objects, actors, techniques, devices, and institutional and spatial arrangements" (864; see also Cambrosio, Limoges, and Hoffman 1992; Epstein 1995, 408-37; 1996; Collins and Evans 2007). These networks produce, reproduce, and disseminate knowledge and/or performances, and Eyal argues that scholars must examine the mechanisms that influence links to and cooperation with such networks.

Though we certainly do not suggest that lay judges in Rwanda were able to accomplish tasks better than credentialed judges, the case of Rwanda presents a situation in which the need for speedy execution of tasks (in this case, criminal trials) trumped other considerations. In line with scholarship on the transformative power of mass violence, the genocide precipitated the need for gacaca court judges, thus shifting institutional arrangements and boundaries such that laypeople worked in tandem with their communities to perform the work of the judiciary. Guided by the sociology of expertise, our question, then, is what arrangements had to be in place for the tasks of the gacaca courts to be accomplished?

\section{RWANDA'S GACACA COURTS AND THE INYANGAMUGAYO}

The 1994 Genocide Against the Tutsi left between eight hundred thousand and one million two-hundred thousand people dead and millions displaced 
(Lemarchand 2013). ${ }^{6}$ In the aftermath of the violence, the UN Security Council swiftly created the International Criminal Tribunal for Rwanda (ICTR). This tribunal was in Arusha, Tanzania, and had jurisdiction over war crimes, crimes against humanity, and genocide committed in Rwanda or by Rwandans in 1994 (ICTR Statute 1994).

The ICTR was meant to try those deemed most responsible for the violence, and it indicted ninety ${ }^{7}$ individuals prior to closing in 2015. Consequently, the hundreds of thousands of Rwandan civilians who had participated in the genocide did not fall under the ICTR's jurisdiction, and the new Rwandan government began searching for people suspected of participating in the genocide and transporting them to Rwandan prisons in 1995 (Clark 2010; Bornkamm 2012). An estimated 120,000 people were brought to facilities that were built to hold forty-five thousand people (International Center for Prison Studies 2013), and the government began trying these individuals through the existing court system. However, it soon became clear that this was not a viable option due to the large caseload and the lack of trained legal professionals.

The Rwandan government consequently decided to modify a mechanism of dispute resolution-known as gacaca courts-to try suspected génocidaires. Gacaca loosely translates to "grass," and pre-colonial gacaca court hearings took place in schoolyards, empty marketplaces, and other public spaces as a response to petty crimes and disagreements. Community elders presided over these trials, though they became an officially sanctioned court system for petty crimes during the 1940s, illustrating that gacaca evolved into an institution associated with state power (Ingelaere 2016). The conciliatory and informal nature of gacaca remained core to the courts' endeavors after colonialism (Reyntjens 1990), however, and grave crimes generally remained under the jurisdiction of Rwanda's existing court system, where judges and lawyers who had typically received at least some credentials had professional jurisdiction (Prinsloo 1993). ${ }^{8}$

The government greatly modified the gacaca courts in the aftermath of the violence, creating a system that blended informal and formal legal practices (for detailed information, see Waldorf 2006; Clark 2010; Bornkamm 2012; Nyseth Brehm, Uggen, and Gasanabo 2014; Chakravarty 2015; Palmer 2015; Ingelaere 2016). ${ }^{9}$ The post-genocide courts-known as inkiko gacaca but shortened here to gacaca-had close ties to the state, which mandated their creation through a series of decrees known as Organic Laws. Also unlike the previous gacaca courts, the new

6. An estimated two-hundred-fifty thousand people were raped (United Nations 1996), and many were victimized in other ways (Mullins 2009), though see Lemarchand (2013) on victimization estimates. For more history, see Lemarchand (1970), Newbury (1988), Prunier (1995), Des Forges (1999), Mamdani (2001), Straus (2006), and Fujii (2011).

7. The ICTR website cites ninety-three individuals, though this counts one individual twice and includes two others who were indicted for contempt of court.

8. As Jones $(2009,81)$ discusses, the Rwandan legal system prior to the genocide was rife with issues and often facilitated impunity, due in part to lack of independence from the state. While some of those who were appointed to positions within the national court system did not have legal training, many others had completed schooling and relevant training for their professions.

9. As Ingelaere (2016) explains, the UN High Commissioner for Human Rights suggested as early as 1996 that gacaca could play a role in responding to genocide-related crimes. 
courts had jurisdiction over more serious crimes, as the government decided to shift all but the most serious genocide-related cases to the gacaca courts. ${ }^{10}$ These courts were operational at the cell (akagari) and sector (umurenge) levels of geographic administration, which were small geographic areas akin to villages and counties. Cases were tried in the geographic regions where the crimes had occurred, with courts at the cell level trying less serious crimes (such as looting) and courts at the sector level trying comparatively more serious ones (such as genocidal murder). Adult members of communities were expected to attend and be actively involved in the trials.

Per newly instituted Organic Laws, Rwandans elected lay members of communities to preside over the post-genocide gacaca courts as judges, or inyangamugayo. ${ }^{11}$ Inyangamugayo generally translates to "trustworthy person" or "person of integrity," and the position was, notably, unpaid. Unlike judges in the existing Rwandan justice system, legal training and credentials were not required to serve as inyangamugayo. Thus, although judges in pre-genocide gacaca trials did not have legal training — as they were community elders presiding over small disputes-laypeople adjudicating grave crimes represented a significant departure from Rwandan legal practice. Rather, inyangamugayo needed to fulfill the following criteria stipulated in Article 7 of Presidential Order Number 12/01:

a) To be of Rwandan nationality;

b) To have his or her residence in the cell where he or she needs to present his or her candidature;

c) To be at least twenty-one years old;

d) To be a person of good morals and conduct;

e) To be truthful and characterized by a spirit of sharing;

f) Not to have been sentenced to a penalty of at least six months of imprisonment; ${ }^{[12]}$

g) Not to have participated in genocide or other crimes against humanity;

h) To be free from sectarianism; and

i) To have no history of indiscipline.

The government instructed adult members of cells to gather in 2001 to elect the inyangamugayo. During the election process, community members could propose candidates before the General Assembly, which was comprised of the voting-age Rwandans (eighteen years and older) who resided in each cell. Those present could then express opinions about the candidates, which involved supporting the values of those who they thought acted with integrity and denouncing the

10. The courts had jurisdiction over crimes committed in Rwanda between October 1, 1990, and December 31, 1994. Suspects were divided into three categories (Organic Law 13/2008). Category 1 was reserved for organizers of the genocide, officials and leaders who participated or incited participation, and those who committed rape and sexual torture. Category 2 included those who tortured others or defiled their bodies, killed or intended to kill, or served as accomplices in such acts. Finally, Category 3 was comprised of property offenders. Some of the Category 1 offenders were tried in the national courts.

11. The bench originally consisted of nineteen and was later reduced to fourteen and nine, with varying numbers needed to obtain a quorum and reach sentencing decisions. The precise number on the bench also varied slightly across communities.

12. A 2007 law added the obligation that judges should also be free from genocide ideology. 
candidates they considered unqualified. Candidates who were denounced were typically rejected, and criteria for rejection often included alcoholism, adultery, dishonesty, failure to pay debts, and committing violence, among other attributes or actions (CCM 2012).

After agreeing on the candidates, residents voted for a bench of judges, and those who received the most votes were officially elected. While there are no data (to our knowledge) on the number of people who refused to accept the position, much evidence suggests that the vast majority of people accepted their nominations (Clark 2010). Each individual then repeated the following statement as he or she was sworn in: "I, in the name of God Almighty, solemnly swear to the Nation to honestly fulfill the mission entrusted to me by complying with the law; to always be guided by the spirit of impartiality and search for the truth; and to make justice triumph."

In total, more than 250,000 men and women were chosen through community elections to staff over 12,000 courts. ${ }^{13}$ Most did not have any prior legal training, and some were illiterate (Honeyman et al. 2004; Clark 2010). While time did not allow for years of training, all inyangamugayo underwent several weeks of preparation. To facilitate this training, government officials first trained advanced law students and magistrates on the new laws governing the gacaca courts (Gacaca Report Summary 2012). In turn, these individuals taught groups of inyangamugayo about how gacaca courts were to function and the punishments they were to give (Bornkamm 2012). Specifically, panels of judges were responsible for reaching a verdict and for assigning the punishment, and they were given sentencing guidelines that instructed them to base punishments on the category of crime, confession, and, if applicable, time to confession. As such, the judges had the power to assign prison sentences up to a life sentence without possibility of release, though punishments for less serious crimes (such as property crimes) typically involved fines that convicted individuals were supposed to pay to victims or their families.

Judges also received training on how to gather information-a critical component of their duties because there were no lawyers in the gacaca court system. Preparation likewise included discussions of ethics as well as the judges' place within the broader justice system. Brief subsequent trainings ${ }^{14}$ also covered security at the trials, conflict resolution, human rights, how to work with traumatized witnesses, and how to assist those victimized by sexual violence, among other topics (Gacaca Report Summary 2012; see Bornkamm 2012 for more on training).

While we emphasize the tasks and problems that the inyangamugayo and their communities addressed, it is important to note that the majority of existing scholarship on the gacaca courts has critically examined the laws and processes governing the trials. Early critiques highlighted the lack of due process, pretrial detention, the absence of lawyers, and the courts' emphasis on confessions, among other procedural legal issues (Sarkin 2001; Corey and Joireman 2004; Fierens 2005; Schabas

13. While more men were elected than women, the proportion of women judges rose as (mostly men) judges were replaced when it came to light that they had participated in the genocide. Exact statistics are not available, however, though fewer than 200,000 judges staffed the courts at their outset.

14. The pilot phase resulted in several changes to the laws governing the gacaca courts, influencing the need for additional training for inyangamugayo in 2004. 
2005; Waldorf 2006; Apuuli 2009). Others have argued that the gacaca courts were too tightly tied to the state and have thus suggested that they functioned as a form of state power, emphasizing some crimes at the expense of others (Burnet 2008; Rettig 2008; Thomson 2011; Chakravarty 2015). ${ }^{15}$

Here, we do not examine the quality of the inyangamugayo's work or how legal practices were enacted within the courts. We likewise do not assess the role of the state, though the state likely vested the inyangamugayo with at least some authority when it dictated that community members should elect inyangamugayo and set the parameters for their election. Rather, we assess what facilitated these laypeople in carrying out tasks typically undertaken by credentialed professionals. Put another way, what mechanisms and arrangements enabled the inyangamugayo to undertake their duties once they had stepped into the new roles?

\section{METHODOLOGY}

We rely on forty-six interviews we conducted with former inyangamugayo in Rwanda in June and July 2015. Interviews were an appropriate methodology because they enabled us to learn about how the inyangamugayo approached their tasks and problems, which could not be understood from secondhand sources or even court ethnographies. Additionally, interviews shed light on community members' links to and cooperation with the inyangamugayo as they undertook their work, highlighting the networks of actors and arrangements that supported the gacaca court processes.

Participants were selected through a stratified random sampling procedure. Specifically, we chose three sectors near the capital city of Kigali: Gikondo, Gahanga, and Masaka. Although proximity to a central location partially guided this choice, these sectors were also chosen due to their comparatively urban (Gikondo) and semirural (Gahanga, Masaka) compositions, as we further address below.

Using a list of all gacaca court trials, we randomly selected twenty trials from each of the three sectors using a random number generator. Then, working in the gacaca court archives in Kigali, we identified all inyangamugayo involved in the randomly selected trials. This involved judges who served in cell, sector, and appeals courts (which also functioned at the sector level). We then obtained phone numbers or addresses through local contacts, contacted these individuals by phone or at their homes, and asked them to participate in the study. Participation was voluntary, though no judges who still resided within the sectors declined participation. We were, however, unable to interview some judges who had since relocated.

The first author administered the interviews with a small research team. ${ }^{16}$ Respondents were able to conduct the interview in English, French, or Kinyarwanda.

15. We unfortunately cannot address each of these important critiques within one article, though we refer the reader to the aforementioned works for additional information.

16. Permission from the National Commission for the Fight Against Genocide (CNLG), as well as from the presidents of the respective sectors, was granted for this study. The Director General of Research of CNLG assisted the first author in accessing information on gacaca court trials. 
All chose Kinyarwanda, and the interviews were thus conducted with translators, with the exception of those conducted by one member of the research team whose first language was Kinyarwanda. All interviews took place in or around respondents' homes and lasted between one and two hours. Interviews followed a semi-structured interview guide that had been translated and back-translated into Kinyarwanda. Generally, each interview addressed participants' lives before and during 1994 and their subsequent involvement in the gacaca courts. Interviews also included discussions of their duties as inyangamugayo, their decision-making processes, and their opinions of court procedures and outcomes.

Twenty-five of the respondents were men; twenty-one were women. Although it is difficult to discuss ethnicity in Rwanda today, ${ }^{17}$ the participants often explained that they were Hutu or Tutsi or noted that they were (or were not) part of the targeted group during the violence. Twenty-six of the interviewees were Tutsi; seventeen were Hutu individuals. Hutu judges typically had risked their lives to save Tutsis during the genocide or had refused to participate in the violence. Additionally, three participants were not born in Rwanda but had lived in the country from a young age. Participants' ages ranged from thirty-three to seventyone at the time of the interviews in 2015. Most had completed at least some years of primary school and provided for their family through farming, though a minority had completed secondary school and held formal employment. ${ }^{18}$ None had any legal training prior to their election.

Numerous scholars have noted the difficulties of conducting research in post-genocide Rwanda (Purdeková 2011; Straus and Waldorf 2011; Thomson 2013). For instance, many suggest that the state tightly regulates narratives related to the genocide. Some may thus worry that respondents would be reluctant to discuss the gacaca courts - which were created by the government. To mitigate this, we stressed that the results would be confidential and that no names or personally identifiable information would be included in any publications resulting from the study. We also spent time talking with participants prior to the interviews to develop rapport (Loyle 2016).

Of course, as with any study employing interviews, our positionality as Western scholars likely influenced the interviews. Yet, it is important to note that the vast majority of respondents were not reluctant to discuss their role in the gacaca courts. While some were noticeably hesitant (and even unwilling) to criticize the courts, many others openly discussed weaknesses and challenges, negative effects on their lives (e.g., grudges held by neighbors), and desires for compensation. This assured us that we had at least developed some rapport with participants. Additionally, as this article examines the tasks of the inyangamugayo rather than their opinions of

17. National laws passed in 2008 and 2013 deem the ethnic categories that existed before the genocide as part of a broader "genocide ideology." The national census likewise no longer includes questions about ethnicity. Thus, while it is possible to discuss previous ethnic categories, we did not directly ask about ethnicity.

18. Most participants served as judges throughout the time that the gacaca courts were operational, though a handful left their positions prior to the courts' closure in 2012. Some attributed their departure to family and work considerations, although several judges we interviewed had been accused of corruption. 
the courts or how well they performed their duties, the content we rely on is less sensitive than other aspects of the interviews.

Upon completion of fieldwork, all interviews were transcribed. We then repeatedly read and analyzed interviews for key themes, which we present below. We modify the grammar in some quotes for clarity, but do not change anything that would alter the meaning of the statements.

Finally, as the forty-six individuals were randomly selected from three sectors (Gikondo, Masaka, and Gahanga), our results arguably generalize to the other inyangamugayo who served in these sectors. That said, the sectors are also comparable to many other sectors across the country. Gikondo has 17,146 residents (Census 2012), and all these individuals live in an urban area, since the sector is within Kigali province. Gahanga and Masaka are each larger sectors in terms of population (27,808 and 39,548 residents, respectively) and geographic size, leading to comparatively lower population densities. These sectors are also more rural, as 42 percent of Gahanga's residents and 49 of Masaka's residents reside in an urban area. Countrywide, the average population of the 416 sectors is 26,134 , and the average percentage of urban residents in a sector is 12 percent. The sectors are thus relatively similar in population, though they are clearly more urban than the average sector.

It is unclear how the relative urbanicity of our three sectors influenced the results, though it is likely that judges in these and other more urban areas knew comparatively fewer of the defendants given the tight-knit nature of rural communities. It is also likely that the judges we interviewed are better educated than judges in comparatively more rural sectors and that there were more women judges. As there is no comprehensive (public) list of all inyangamugayo, these possibilities should be kept in mind, but unfortunately, they cannot be confirmed.

\section{RESULTS: PRODUCING EXPERTISE AT GACACA}

Our interviews revealed that the inyangamugayo believed their ability to approach tasks and problems - and thus the production of expertise-stemmed from three interconnected factors that were all tied to their social capital. First, the inyangamugayo consistently explained that they were elected because of their reputations as people of integrity. Although the state set integrity as a qualification for their election, our interviews illustrate how the inyangamugayo understood integrity and suggest that the belief that their neighbors viewed them as people of integrity influenced their willingness to become judges. Second, once the inyangamugayo stepped into their roles, they relied on a broader network of actors to undertake their tasks. Most prominently, their fellow community members assisted in numerous aspects of gacaca court work, though state and international actors also played a part. Finally, the inyangamugayo stressed the importance of ensuring their reputations throughout the court process. Specifically, they continually sought to protect their reputations by appearing trustworthy, avoiding corruption, and policing the behavior of their fellow judges. This impression management seemingly was undertaken to ensure that their communities continued to view them as qualified and to sustain cooperation from fellow community members. 


\section{Election Based on Reputation}

As noted above, the Rwandan government instructed adults to gather in their cells to elect the inyangamugayo. During the election process, any adult community member could propose a candidate, and those present could then express opinions about each candidate prior to electing the inyangamugayo through popular vote. There were no campaigns beforehand; rather, those who were elected were often surprised that they were chosen.

As such, many vividly remembered their election day and expressed their initial hesitation. For instance, Julienne, a thirty-seven-year-old resident of Gikondo, recounted how her community had gathered when government officials asked for nominations. She recalled, "I did not want ... to be chosen. The public chose me to be one of the selected people. I stood, and people made a line behind me. If you had a big line behind you, of course you became a judge." Noël, a sixtyfive-year-old farmer in Gikondo, similarly explained: "At the beginning, I was surprised. I said, 'I never went to school. I never even completed high school. How am I going to manage being a judge?"”

Julienne, Noël, and the other inyangamugayo with whom we spoke nonetheless accepted the position despite the fact that none of them had formal legal training and that many had not even completed primary school. Reflecting on this, the inyangamugayo explained that they were not elected because of their credentials; rather, they believed they were elected because of their positive reputations and the trust they had earned from fellow citizens, and it was this belief that pushed them toward accepting the position. Indeed, when asked why they stepped into their roles, many participants explained that they agreed to serve as judges because their communities thought they would perform the tasks well. For instance, Noël later noted that his peers had encouraged him: "I knew very well that those people who elected me knew who I was. They told me, 'You will do it."'

As they discussed the perceived trust from their communities, many inyangamugayo highlighted the particular importance of integrity. As Innocent, a fortyseven-year-old businessman in Gikondo, noted, "I think people selected me as a person of integrity. They trusted me." Félicité, a fifty-nine-year-old farmer, further remarked: "Even before the genocide, we were seen as people of integrity." Élina concurred, explaining: "The neighbors know you, your background; you have to have integrity to be chosen." As the government instructed citizens to take integrity into consideration (and as the term inyangamugayo is often translated to "a person of integrity"), this illustrates that the inyangamugayo believed their fellow citizens heeded this call.

Our conversations also shed light on how the inyangamugayo understood integrity. For some, their integrity was based in not having participated in crimes of genocide. Liberatha, a forty-six-year-old farmer, explained:

Of course, you had to be a person of integrity. A person who never killed during [the] genocide. A person who had no accusations. Of course, you had to be a person of integrity. It is on that, that community members [elected me] as a judge ... [at first] I was reluctant. I was not willing to 
participate ... after considering the trust from the community members, of course I decided to join. As I saw that many people of integrity were elected, then I participated.

Mélanie, a forty-two-year-old farmer from Gahanga, likewise noted that "[t]hat day of my election, I was maybe chosen because first I did not participate [in] any killings," while Phenias shared, "I was elected because my neighbors knew I did not participate in killings, even looting others' property." Innocence was thus perceived as a cornerstone of integrity, though Hutu judges were notably more likely than Tutsi judges to mention their innocence as a reason for their election.

For others, being a person of integrity meant being honest and trustworthy. Odette, a fifty-four-year-old farmer from Gahanga, felt strongly that she was elected for her enduring honesty: "[I was elected] because people thought I was an honest person-a person of integrity-and of course I was." In a similar vein, Jean Bosco declared: "We were elected because people judge[d] [us] as always telling the truth." Isaac, a thirty-five-year-old farmer from Gikondo, also highlighted trust when he told us, "[p]eople trusted me because I was not supporting any lie"; while Marceline explained elections by noting that "the people of the same village sat together and tried to choose the honest people" (emphasis added).

Reputations-like those invoked in these statements-are a form of social capital (Fine 2001, 2-3). Reputations are consequently embedded within social relationships, and in this case, participants believed that their reputations as trustworthy, upstanding individuals proved more meaningful than formal credentials. This belief was one of the major reasons that the individuals with whom we spoke decided to accept their new roles.

Of course, we cannot prove the objective morality of the individual inyangamugayo, as reputations are socially constructed and as individuals tend to present themselves in a positive light. Nevertheless, as part of the larger research project, the first author and a research team interviewed eighty-two people who were defendants in the gacaca court system and thirty-six people who testified during the trials as witnesses. While these conversations did not address the reputations of the specific inyangamugayo who were interviewed for this project, each participant was asked about the factors they took into account when they were electing judges.

These interviews confirm the emphasis on reputation as a primary qualification for election, supporting the general perceptions of the inyangamugayo. For instance, a witness from Masaka described what he took into account on election day, noting: "We based [it] on one's behavior, especially on honesty and the importance that they can have in the community." Another witness shared the inyangamugayo's general understanding of integrity, explaining: "First of all, they have to [be] based on the fact that you did not get involved in any killings or any violence. Second, whether you are [an] innocent person; you are an honest person. For those two factors, you could be elected as a judge." A witness from a different sector likewise shared: "They actually had to be respected people with good ideas, and mature opinions ... those who actually fought against genocide, who never committed crimes during [the] genocide."

Some defendants also participated in the elections, and their sentiments were similar. A defendant from Masaka told us: "Judges were not elected because they 
had gone to school. They were elected only because they were people of integrity and people who could actually have good ideas and skills in deciding cases." Another defendant explained, "[w]e could propose names of those that we knew [had] never participated in the genocide," highlighting a common understanding of integrity as linked to innocence and honesty. ${ }^{19}$ These and other interviews with community members thus support the judges' perceptions that it was their reputations-specifically that they had not participated in the genocide and that they were honest and trustworthy - that made them suitable in the eyes of their communities to sit in judgment over complex and painful proceedings.

\section{Forging Networks of Expertise}

As the inyangamugayo began their work, other actors and institutions were critical for the completion of their duties. This aligns with Eyal's (2013) conception of expertise, which again suggests that expertise involves a network that links actors, institutional arrangements, objects, and other social phenomena. In the case of Rwanda's inyangamugayo, their work was completed with the assistance of many others-most prominently their fellow community members, but also state and international actors - at every stage of the transitional justice process.

Although these individuals were generally elected based on their reputations, formal training was not disregarded, and the inyangamugayo underwent several brief training sessions after their election. These trainings were created and implemented through a collaboration of Rwandan government officials, legal professionals, and many individuals from other countries (Bornkamm 2012; Kaitesi 2014), demonstrating the network of individuals who came together to aid the inyangamugayo as they began their important work.

After training was complete, the first step was to gather details regarding who had committed crimes and who had been victimized to generate a list of suspected perpetrators and to prepare witnesses and evidence for trial. As Phenias, a fifty-twoyear-old farmer from Gahanga, described: "The period of information collection was the core of gacaca activities." Importantly, this work relied heavily on community members, illustrating the networks that were forged to accomplish the judges' tasks. Épiphanie, a sixty-year-old farmer from Gikondo, explained: "The [population] would come together, they would give us information on what they saw during the genocide, or even what they had heard. [We] would write everything that people told us, and [that is how] we based files." ${ }^{20}$ Community members were thus vital to the inyangamugayo as they began their tasks.

Upon gathering information, the inyangamugayo were primarily occupied with holding trials. These trials occurred publicly, and members of the community were

19. As noted above, not having participated in the genocide was one of the official criteria. Nevertheless, there were many official criteria (such as being twenty-one), and this was the only one that consistently surfaced during interviews.

20. While many judges were not able to read or write, each court elected a secretary. This individual kept detailed records on trial events. The secretary also was responsible for completing court paperwork, such as forms that explained the outcome of each case. 
expected to be present and participate in their proceedings. Specifically, after summoning the defendant - a task that sometimes required collaboration across communities, as individuals had often moved, died, or were in hiding-the trial would unfold in a public setting, and community members once again provided testimony about what they had witnessed during the genocide.

These tasks, accomplished with assistance from their communities, enabled the inyangamugayo to assess whether people were guilty of genocide and to hand down punishments accordingly. In property cases, the punishment was mostly restitution, and those found guilty were expected to pay back the value of what was stolen. In such cases, community members were likewise essential in determining the fines that were allocated. In Esther's words:

We could base on a list given by the victim. We could go together with the community members through the list. Then we actualize the price of the items destroyed in collaboration with community members. Community members could help us determine the price of products mentioned within the list. Because, for example, a bed which was destroyed in 1994, its value changed, and we had to actualize the price according to the market price.

Pascal, a forty-one-year-old farmer, likewise explained that when his bench needed to ascertain the price of stolen property, such as a cow, they would convene a community meeting to debate and set the price.

Similarly, Jean Damascène informed us that while it was the judges who would sit together, deliberate over evidence, and eventually sign off on a sentence, disagreement on the bench sometimes required further consultation with members of the community. As he explained, in such an instance, the judges would "adjourn, and then reconvene the next day and gather more information from community members." Olive, a fifty-six-year-old tailor, further attests to such an occurrence, explaining that judges rigorously collected evidence and testimony (both for and against the defendant) with the aid of the community. In her words:

We based on witnesses, the witnesses on both sides-those ones witnessing against and those ones who were witnessing in favor of the defendant. We could gather information from both, but again, in our court we started going to the field to gather more information after getting it from these two sources of information to make sure that we go by the right information.

In line with this, Phenias explained that his court relied on the community heavily during particularly difficult trials. He shared that if his bench of judges failed to reach consensus on a trial decision, they would postpone and "invite the defendants and the witnesses or the public to discuss the matter and try to make a decision together."

These narratives highlight the importance of the community in aiding the judges as they went about their tasks. From gathering information to holding trials and reaching verdicts, members of each community worked with the 
inyangamugayo at each step of the court process. International and state actors were likewise consequential, especially in training the inyangamugayo, but also in other ways we have not mentioned here, such as providing police when judges were worried about their safety or responding to legal questions about particularly tough cases. This network of actors and arrangements thus proved critical to the inyangamugayo throughout the ten years of their service.

\section{Ensuring Reputations}

Throughout these years, the inyangamugayo continued to rely heavily on the reputations that brought them to their position in the first place. During our conversations, the judges consistently stressed the importance of guarding their reputations by appearing trustworthy, steering clear of corruption, and policing the behavior of their fellow judges. This, in turn, would enable them to sustain their qualification to serve as a judge and to continue to rely on their community members for assistance.

For many judges, ensuring that members of their communities continued to view them as people of integrity — and thus maintaining their social capital—was linked to ensuring that people continued to view them as trustworthy. Paul, a sixty-one-year-old who works in construction, explained that this meant constantly being aware of confidentiality: "You could not go around mentioning somebody's name ... you were not allowed to do that. It required [you] to be careful and again to be a person of integrity."

Other judges similarly highlighted their critical ability to refrain from discussing sensitive information in front of others, thus maintaining their trustworthy status. For example, sixty-two-year-old Jacques noted that all decisions had "to be confidential from the beginning," while Hope likewise emphasized the importance of enduring confidentiality, elaborating that judges "were supposed to keep what we discussed in deliberation confidential." Again, the trials occurred publicly, and as we discussed above, the judges often relied on their fellow community members for assistance with certain aspects of their decisions. Judges with whom we spoke nonetheless stressed that confidentiality was key, especially when it came to their private deliberations as a bench and to particularly sensitive trials, such as those involving sexualized violence.

Apart from continuing to appear trustworthy, myriad judges likewise discussed the importance of remaining free from corruption and thus maintaining their image as honest community members. To them, this involved stepping down from the bench when necessary and refraining from taking bribes. Pertaining to the former, many judges explained it was their duty to remove themselves from the bench if they were concerned about conflicts of interest. Liberatha shared: "Of course, you were allowed to decree a conflict of interest in any case you had ... 'I do not want to participate in this case, because this is my friend, this is my relative."

Though not all inyangamugayo followed this rule, ${ }^{21}$ several participants shared instances in which they did. Épiphanie told us that she stepped down anytime she

21. Some inyangamugayo instead allowed their family and friends to benefit from their positions (Chakravarty 2015). 
felt that her preconceived notions about a defendant's behavior were too strong. She explained: "When it came to a person that I knew [had] participated in genocide, I never served on the judge's bench. I could join the witnesses and tell the judges what the person did during the genocide." Philippe, a thirty-seven-year-old farmer, similarly shared a story about recusing himself when his own father appeared for trial to avoid the appearance of corruption. He explained: "We were not allowed to judge a case of a relative. [My dad] was tried in the same court, but I had to step down. I had to go from the judge's bench and sit in the audience. I was not even allowed to sit with the judges to deliberate."

Another core aspect of avoiding corruption and maintaining an image as an honest person involved refusing bribes. Jean, a fifty-three-year-old farmer from Gahanga, explained: "There is a person who wanted to give me a bribe of one hundred thousand. This person was claiming that he/she was innocent. I did not take that bribe." Mélanie also noted that she did not take any money, noting that: "When we are judges, we have as a duty not to accept bribes or corruption."

Others explained that the bribe did not have to be monetary, as members of their communities tried to exploit friendships to receive more favorable sentences. Olive shared: "Many could want to befriend you to show you that they are innocent, to be your friend to make sure that you sympathized with them." Olive later emphasized the importance of remaining impartial, however, again emphasizing the importance of her reputation. Numerous others likewise explained that they needed to treat everyone equally rather than providing favors for their friends, again stressing the need to protect their reputations.

Finally, while the inyangamugayo strove to present themselves as people of integrity and avoid corruption, they also paid attention to the behavior and reputations of their fellow judges. Typically, this involved holding their fellow judges to the same standards to which they were holding themselves. More broadly, this involved safeguarding the general reputations of their courts, which would in turn influence their personal reputations. Likewise, it also invoked a degree of boundary policing similar to efforts to control the behavior of professionals in other contexts.

Mélanie relayed: "Before we start trial, we first of all invite the defendant. When he is present, we make sure that there is no relative of the defendant among the judges. If we find that there is any relative among the judges, we set him aside" (emphasis added). Olive likewise explained that resisting bribes and guarding against exploitation was often a group endeavor, as the inyangamugayo could reinforce one another's commitment to ethical behavior. In her words:

I remember our court was never involved in corruption cases. It was never involved because we could listen to the only person who was willing to give us information but for those who could come wanting to give us bribes, we never accepted that.

In cases where their collective resistance of bribes failed, and someone did take a bribe or engage in otherwise corrupt behavior, the judges often sought to remove him or her from their bench. Épiphanie recalled that a judge was expelled from her court. She explained: "In our court, there was a person ... [who] wanted 
to ... introduce corrupt tendencies to our court. He wanted to make us corrupt ... But our president had to expel him from the court." Hope, a forty-seven-year-old farmer from Gahanga, shared a similar story. She remembered: "In our court, there was a woman ... whose father was a defendant. She could always say that her father's trial was not fair. We then decided to expel her from the court."

Espérance, a seventy-one-year-old from Gikondo, likewise reports an experience in which judges were expelled from the judges' bench. In her case, she contacted several government officials after observing corruption, which resulted in the forcible removal of the individuals. In her words:

But there is one time when I was with gacaca that I wanted to withdraw because I could see some people vacating into corruption ... and I was not happy with that. I was not happy with that, I even contacted top officials in the government, telling them that I am going to resign from gacaca. Then they asked me, "Why? Why? Why do you have to resign?" I told them that gacaca is not doing what it is supposed to do. "If you do not intervene, I am going to get out of gacaca." Fortunately, those people were forced to get out of gacaca.

Thus, in these instances and in many others, judges who failed to uphold their reputations and to live up to the meaning of inyangamugayo were removed from their benches by their fellow judges. More broadly, this further underscores the importance of the inyangamugayo's reputations, from the time they were elected to the time that the courts closed in 2012.

\section{DISCUSSION AND CONCLUSION}

This article illustrates how the processes that typically determine who undertakes professional tasks can be upended in a transitional justice setting. In the case of Rwanda's gacaca courts, laypeople completed tasks that were previously performed by those with credentials and formal training. More than two-hundred-fifty thousand "nonprofessionals" were elected to oversee prosecutions for genocide, hand down prison sentences, and preside over conversations meant to reconcile the nation.

We suggest that the critical juncture of mass violence influenced Rwanda's justice system such that new conceptions arose regarding the necessary qualities and credentials of a judge. ${ }^{22}$ To make sense of these shifting institutional arrangements, we draw on the sociology of expertise. This approach highlights the importance of analyzing the execution of tasks and suggests that many actors-not just licensed and credentialed professionals - can carry out important tasks in a "superior and speedy" manner (Eyal 2013, 871). In the case of Rwanda, mass violence altered the existing institutional arrangements and precipitated the need for people to preside

22. We do not suggest that the mass violence is the only reason that these conceptions arose. For instance, the previous gacaca system's reliance on community elders (rather than trained officials) may have likewise influenced this shift and may have influenced people's willingness to accept the gacaca courts. 
over hundreds of thousands of genocide-related trials. Although we certainly do not claim that the inyangamugayo were superior to licensed judges in their implementation of the law, they were essential to the speedy execution of trials that were beyond the capacity of the national justice system.

In the absence of a formal licensing process, we find that social capital and, in particular, reputations became vital to the election and subsequent work of the inyangamugayo. The Rwandan government instructed citizens to select people of "integrity" to staff the gacaca courts, and although the government thus played a role in constructing this criterion, the forty-six judges we interviewed considered integrity to be of utmost importance. We illustrate that these judges perceived integrity as rooted in innocence, honesty, and trustworthiness and likewise show that their perceptions of how their fellow community members viewed them influenced their decision to accept their nomination as a judge.

Reputation remained important throughout the execution of the judges' tasks, and the inyangamugayo engaged in impression management (Goffman 1959) to uphold their reputations by presenting themselves as people of integrity. This involved steering clear of corruption, such as removing themselves from the bench when there was a conflict of interest and refusing to take bribes. As some inyangamugayo did engage in corrupt behavior, impression management likewise involved policing the behavior of the other inyangamugayo. Such actions were likely undertaken, at least in part, to ensure that the inyangamugayo continued to be seen as qualified to undertake their tasks and that they could rely on assistance from their communities.

The election of judges based largely on reputation differs from the selection of judges for other Rwandan courts. As in the United States, pre-genocide judges in Rwanda often needed to acquire at least some educational credentials that helped grant them entry to the profession. Reputations nonetheless likely played a role in their selection, and judges in all contexts arguably safeguard their reputations throughout their tenure. Indeed, professional associations typically regulate their members by asking them to adhere to codes of ethics (Abbott 1983), and professionals have accordingly made claims of morality to ensure their status (Lamont 1992). Scholars have thus documented that judges try to present themselves in a positive light and that they engage in reputation management (e.g., Baum 2009).

Nevertheless, our study suggests that in absence of formal licensing and credentialing, reputations may take on an increased salience. Put another way, when laypeople had to undertake tasks typically pursued by professionals, the importance of reputation became amplified due to the lack of other qualifying characteristics. In the case of Rwanda, the inyangamugayo believe that their reputations for honesty and trustworthiness were the cornerstone of their elections and their subsequent abilities to execute tasks.

We likewise find that the inyangamugayo relied on a network of support to carry out their duties, falling in line with previous scholarship on expertise (Eyal 2013) and further underscoring the importance of social capital in this context. Specifically, the inyangamugayo relied on state and international actors for training, which was instrumental as they stepped into their new positions. Community members were particularly critical, as they collected information about crimes, 
participated in trials, and sometimes even aided in aspects of decision making. Much like reputation, this suggests that the importance of a strong network of support may be amplified in situations where laypeople take on duties previously enacted by professionals.

Again, this article does not take a moral or legal stance regarding the judges' reliance on community members ${ }^{23}$ or the many other elements of the gacaca courts, but instead illustrates the network that was forged to accomplish important tasks. In line with this, our article does not address the quality of the inyangamugayo's work. For instance, an examination of their accuracy in decision making would require in-depth information about specific cases, evidence, and legal procedures, which is beyond the scope of this study. We also cannot speak to whether the individuals we interviewed were actually ethical in their decision-making processes; in fact, some inyangamugayo were quick to share stories of others' corrupt actions but would rarely point a finger at themselves. This falls in line with social desirability bias, as it is likely that these individuals overemphasized positive traits and behavior and underemphasized (or did not report) less desirable traits or behavior. Although this must be kept in mind, it also points to their continual efforts to fulfill the image of a "person of integrity." All people engage in identity negotiation and impression management, and these judges likewise appeared eager to maintain their image as inyangamugayo during our interviews.

As we have relied heavily on the inyangamugayo's perceptions, future research should examine community members' perceptions of the inyangamugayo. Scholars should likewise examine how reputations may have influenced gacaca court sentencing decisions, as previous work has suggested that judges make decisions based on institutional constraints, preferences, and incentives-including how they wish to be perceived by the public - rather than via a strictly orthodox interpretation of the law (Epstein, Williams, and Posner 2013; Klement and Neeman 2013). Additionally, studies should examine whether reputation becomes more salient in other settings where laypeople (or at least people without formal credentials) undertake the work of professionals and whether and how networks of support aid these individuals in their work.

This case study has demonstrated the importance of social capital in a situation where laypeople were tasked with the duties of professionals. As we noted above, laypeople have taken on the duties of professionals in other transitional justice settings, such as in the case of South Africa's Truth and Reconciliation Commission or Uganda's mato oput. Critical junctures likely shift institutional arrangements that affect other forms of expertise as well. For instance, Syria's White Helmets constitute a contemporary example of laypeople providing muchneeded medical assistance in crisis situations. Yet, while boundaries around tasks and other elements of expertise may shift following critical junctures, the new institutional arrangements are likely impermanent. The inyangamugayo, for instance, did not become judges after the gacaca courts closed in 2012. Many did become mediators in their communities, however, suggesting that boundaries do not simply

23. Such reliance may have broken confidentiality, and power structures within communities likely influenced which members of the community were able to provide input during the proceedings. 
shift "back" to where they were prior to the critical juncture and further underscoring the transformative effect of mass violence.

\section{REFERENCES}

Abbott, Andrew. "Professional Ethics." American Journal of Sociology 88 (1983): 855-85.

- The System of Professions: An Essay on the Division of Expert Labor. Chicago: University of Chicago Press, 1988.

Apuuli, Kasaija Phillip. "Procedural Due Process and the Prosecution of Genocide Suspects in Rwanda." Journal of Genocide Research 11 (2009): 11-30.

Baines, Erin K. "The Haunting of Alice: Local Approaches to Justice and Reconciliation in Northern Uganda." International Journal of Transitional Justice 1, no. 1 (2007): 91-114.

Baum, Lawrence. Judges and Their Audiences: A Perspective on Judicial Behavior. Princeton, NJ: Princeton University Press, 2009.

Berry, Marie E. Women, War, and Power in Rwanda and Bosnia-Herzegovina. New York: Cambridge University Press, 2018.

Bond, Rod, and Nigel Lemon. "Training, Experience, and Magistrates' Sentencing Philosophies: A Longitudinal Study." Law and Human Behavior 5, no. 2-3 (1981): 123-39.

Bornkamm, Paul Christoph. Rwanda's Gacaca Courts: Between Retribution and Reparation. New York: Oxford University Press, 2012.

Bourdieu, Pierre. The State Nobility: Elite Schools in the Field of Power. Stanford, CA: Stanford University Press, 1996.

Burnet, Jennie. "The Injustice of Local Justice: Truth, Reconciliation and Revenge in Rwanda." Journal of Genocide Studies and Prevention 3, no. 2 (2008): 173-93.

Cambrosio, Alberto, Camille Limoges, and Eric Hoffman. "Expertise as a Network: A Case Study of the Controversies Over the Environmental Release of Genetically Modified Organisms." In The Culture and Power of Knowledge, edited by Nico Stehr and Richard V. Ericson, 341-61. Berlin: Walter de Gruyter, 1992.

Carpenter, Anna E., Alyx Mark, and Colleen F. Shanahan. "Trial and Error: Lawyers and Nonlawyer Advocates." Law and Social Inquiry 42 (2016): 1023-1057. doi:10.1111/lsi.12252.

Census. "Thematic Report: Population Size, Structure, and Distribution." Fourth Population and Housing Census. Rwanda. Kigali: National Institute of Statistics, 2012.

Chakravarty, Anuradha. Investing in Authoritarian Rule: Punishment and Patronage in Rwanda's Gacaca Courts for Genocide Crimes. New York: Cambridge University Press, 2015.

Cheh, Mary M. "Should Lawyers Participate in Rigged Systems: The Case of the Military Commissions." Journal of National Security Law and Policy 375 (2005): 1-53.

Clark, Phil. The Gacaca Courts, Post Genocide-Justice and Reconciliation in Rwanda: Justice Without Lawyers. Oxford: Oxford University Press, 2010.

Collins, Harry, and Robert Evans. Rethinking Expertise. Chicago: University of Chicago Press, 2007.

Conflict Management of the National University of Rwanda (CCM). "Gacaca Courts in Rwanda." Report published by the CCM. Kigali: CCM, 2012.

Corey, Allison, and Sandra F. Joireman. "Retributive Justice: The Gacaca Courts in Rwanda." African Affairs 103, no. 410 (2004): 73-89.

Des Forges, Alison. Leave None to Tell the Story: Genocide in Rwanda. New York: Human Rights Watch, 1999.

Diamond, Shari Seidman. "Revising Images of Public Punitiveness: Sentencing by Lay and Professional English Magistrates." Law and Social Inquiry 15, no. 2 (1990): 191-221.

Ellman, Stephen. "Struggle and Legitimation." Law and Social Inquiry 20, no. 2 (1995): 339-48.

Epstein, Lee, William M. Landes, and Richard A. Posner. The Behavior of Federal Judges: A Theoretical and Empirical Study of Rational Choice. Cambridge, MA: Harvard University Press, 2013. 
Epstein, Steven. "The Construction of Lay Expertise: Aids Activism and the Forging of Credibility in the Reform of Clinical Trials." Science, Technology, and Human Values 20, no. 4 (1995): 408-37. . Impure Science: Aids, Activism, and the Politics of Knowledge. Berkeley, CA: University of California Press, 1996.

Eyal, Gil. "For a Sociology of Expertise: The Social Origins of the Autism Epidemic." American Journal of Sociology 118, no. 4 (2013): 863-907.

Faulconbridge, James, and Daniel Muzio. "Professions in a Globalizing World: Toward a Transnational Sociology of the Professions." International Sociology 27, no. 1 (2012): 136-52.

Fierens, Jacques. "Gacaca Courts: Between Fantasy and Reality." Journal of International Criminal Justice 3 (2005): 896-919.

Fine, Gary. Difficult Reputations: Collective Memories of the Evil, Inept, and Controversial. Chicago: University of Chicago Press, 2001.

Fujii, Lee Ann. Killing Neighbors: Webs of Violence in Rwanda. Ithaca, NY: Cornell University Press, 2011.

Gacaca Report Summary. "Summary of the Report Presented at the Closing of Gacaca Court Activities." National Service of Gacaca Jurisdictions. Kigali, Rwanda. June 18, 2012. On file with the first author.

Garbett, Claire. "Transitional Justice and 'National Ownership': An Assessment of the Institutional Development of the War Crimes Chamber of Bosnia and Herzegovina." Human Rights Review 13, no. 1 (2012): 65-84.

Goffman, Erving. The Presentation of Self in Everyday Life. New York: Doubleday Anchor, 1959.

Gready, Paul, and Simon Robins. "Rethinking Civil Society and Transitional Justice: Lessons from Social Movements and 'New' Civil Society." International Journal of Human Rights 21, no.7 (2010): 956-75.

Green, Thomas M. "Police as Frontline Mental Health Workers: The Decision to Arrest or Refer to Mental Health Agencies." International Journal of Law and Psychiatry 20, no. 4 (1997): 469-86.

Hagan, John. Justice in the Balkans: Prosecuting War Crimes in the Hague Tribunal. Chicago: Chicago University Press, 2003.

Honeyman, Catherine, Shakirah Hudani, Alfa Tiruneh, Justina Hierta, Leila Chirayath, Andrew Iliff, and Jens Meierhenrich. "Establishing Collective Norms: Potentials for Participatory Justice in Rwanda." Peace and Conflict: Journal of Peace Psychology 10, no. 1 (2004): 1-24.

Hughes, Mélanie M., and Aili Mari Tripp. "Civil War and Trajectories of Change in Women's Political Representation in Africa, 1985-2010." Social Forces 93, no. 4 (2015): 1513-40.

Ingelaere, Bert. Inside Rwanda's Gacaca Courts: Seeking Justice After Genocide. Madison: University of Wisconsin Press, 2016.

International Center for Prison Studies. 2013. http://www.prisonstudies.org.

Ivanisevic, Bogdan. "The War Crimes Chamber in Bosnia and Herzegovina: From Hybrid to Domestic Court." International Center for Transitional Justice, 2008. https:/www.ictj.org/ sites/default/files/ICTJ-FormerYugoslavia-Domestic-Court-2008-English.pdf.

Johnstone, Gerry. "Penal Policy Making: Elitist, Populist or Participatory?" Punishment and Society 2, no. 2 (2000): 161-80.

Jones, Nicholas. The Courts of Genocide: Politics and the Rule of Law in Rwanda and Arusha. New York: Routledge, 2009.

Kaitesi, Usta. Genocidal Gender and Sexual Violence: The Legacy of the ICTR, Rwanda's Ordinary Courts and the Gacaca Courts. Cambridge: Intersentia, 2014.

Kestnbaum, Meyer. "Citizen-Soldiers, National Service and the Mass Army: The Birth of Conscription in Revolutionary Europe and North America." Comparative Social Research 20 (2002): 117-44.

Klement, Alon, and Zvika Neeman. "Does Information About Arbitrators' Win/Loss Ratios Improve Their Accuracy?" Journal of Legal Studies 42, no. 2 (2013): 369-97.

Kritz, Neil J. Transitional Justice: How Emerging Democracies Reckon with Former Regimes. Washington, DC: US Institute of Peace, 1995.

Kuhlmann, Ellen. "Sociology of Professions: Towards International Context-Sensitive Approaches." South African Review of Sociology 44, no. 2 (2013): 7-17. 


\section{LAW \& SOCIAL INQUIRY}

Lamont, Michèle. Money, Morals, and Manners: The Culture of the French and the American UpperMiddle Class. Chicago: University of Chicago Press, 1992.

Larson, Magali S. The Rise of Professionalism: A Sociological Analysis. Berkeley: University of California Press, 1977.

Lefranc, Sandrine, and Frédéric Vairel. "The Emergence of Transitional Justice as a Professional International Practice." In Dealing with Wars and Dictatorships, edited by Liora Israel and Guillaume Mouralis, 235-52. The Hague: TMC Asser Press, 2014.

Lemarchand, René. Rwanda and Burundi. New York: Praeger, 1970.

—. "Rwanda: The State of Research." Online Encyclopedia of Mass Violence, 2013. http:// citeseerx.ist.psu.edu/viewdoc/download?doi $=10.1 .1 .692 .7703 \&$ rep $=$ rep $1 \&$ type $=$ pdf.

Liu, Sida. "The Legal Profession as a Social Process: A Theory on Lawyers and Globalization." Law and Social Inquiry 38, no. 3 (2013): 670-93.

. "Overlapping Ecologies: Professions and Development in the Rise of Legal Services in China." Sociology of Development 3, no. 3 (2017): 212-231.

Loyle, Cyanne E. "Overcoming Research Obstacles in Hybrid Regimes: Lessons from Rwanda." Social Science Quarterly 97, no. 4 (2016): 923-35.

Madlingozi, Tshepo. "On Transitional Justice Entrepreneurs and the Production of Victims." Journal of Human Rights Practice 2, no. 2 (2010): 208-28.

Mahoney, James. "Path Dependence in Historical Sociology." Theory and Society 29, no. 4 (2000): $507-48$.

Mamdani, Mahmood. When Victims Become Killers: Colonialism, Nativism, and Genocide in Rwanda. Princeton, NJ: Princeton University Press, 2001.

Mann, Michael. The Sources of Social Power Volume 4: Globalizations, 1945-2011. New York: Cambridge University Press, 2013.

Markoff, John. Waves of Democracy: Social Movements and Political Change (Vol. 10). New York: Sage, 1996.

McEvoy, Kieran. "Beyond Legalism: Towards a Thicker Understanding of Transitional Justice." Journal of Law and Society 34, no. 4 (2007): 411-40.

. "What Did the Lawyers Do During the 'War'? Neutrality, Conflict and the Culture of Quietism." Modern Law Review 74, no. 3 (2011): 350-84.

Michelson, Ethan. "The Practice of Law as an Obstacle to Justice: Chinese Lawyers at Work." Law and Society Review 40, no. 1 (2006): 1-38.

—. "Lawyers, Political Embeddedness, and Institutional Continuity in China's Transition from Socialism." American Journal of Sociology 113, no. 2 (2007): 352-414.

Moore, Barrington. Social Origins of Dictatorship and Democracy; Lord and Peasant in the Making of the Modern World. Boston: Beacon Press, 1966.

Mullins, Christopher W. "He Would Kill Me with His Penis': Genocidal Rape in Rwanda as a State Crime." Critical Criminology 17, no. 1 (2009): 15-33.

Newbury, Catharine. The Cohesion of Oppression: Clientship and Ethnicity in Rwanda,1860-1960. New York: Columbia University Press, 1988.

Nyseth Brehm, Hollie, and Shannon Golden. "Centering Survivors in Local Transitional Justice." Annual Review of Law and Social Science 13(2017): 102-21.

Nyseth Brehm, Hollie, Christopher Uggen, and Jean-Damascène Gasanabo. "Genocide, Justice, and Rwanda's Gacaca Courts." Journal of Contemporary Criminal Justice 33, no. 3 (2014): 333-52.

Osiel, Mark. Mass Atrocity, Collective Memory, and the Law. New Brunswick, NJ: Transaction, 1997.

Palmer, Nicola. Courts in Conflict: Interpreting the Layers of Justice in Post-Genocide Rwanda. New York: Oxford University Press, 2015.

Pierson, Paul. Politics in Time: History, Institutions, and Social Analysis. Princeton, NJ: Princeton University Press, 2004.

Prinsloo, M. W. "Recognition and Application of Indigenous Law in Zaire, Rwanda, Burundi and Lusophone Africa." Journal of South African Law (1993): 541-51.

Prunier, Gérard. The Rwanda Crisis: History of a Genocide. New York: Columbia University Press, 1995. 
Purdeková, Andrea. "Even if I Am Not Here, There Are So Many Eyes': Surveillance and State Reach in Rwanda." Journal of Modern African Studies 49, no. 3 (2011): 475-97.

Rettig, Max. "Gacaca: Truth, Justice, and Reconciliation in Postconflict Rwanda?" African Studies Review 51, no. 3 (2008): 25-50.

Reyntjens, Filip. "Le Gacaca ou la Justice du Gazon au Rwanda." Politique Africaine 40 (1990): $31-41$.

Roht-Arriaza, Naomi, and Javier Mariezcurrena. Transitional Justice in the 21st Century: Beyond Truth Versus Justice. Cambridge: Cambridge University Press, 2006.

Sarkin, Jeremy. "The Tension Between Justice and Reconciliation in Rwanda: Politics, Human Rights, Due Process and the Role of the Gacaca Courts in Dealing with the Genocide." Journal of African Law 45, no. 2 (2001): 143-72.

Schabas, William A. "Genocide Trials and Gacaca Courts." Journal of International Criminal Justice 3 (2005): 879-95.

Shaw, Rosalind, Lars Waldorf, and Pierre Hazan. Localizing Transitional Justice: Interventions and Priorities After Mass Violence. Stanford, CA: Stanford University Press, 2010.

Sikkink, Kathryn. The Justice Cascade: How Human Rights Prosecutions Are Changing the World. New York: W.W. Norton, 2011.

Skocpol, Theda. States and Social Revolutions: A Comparative Analysis of France, Russia, and China. New York: Cambridge University Press, 1979.

—. Protecting Soldiers and Mothers: The Political Origins of Social Policy in the United States. Cambridge, MA: Harvard University Press, 1992.

Straus, Scott. The Order of Genocide: Race, Power, and War in Rwanda. Ithaca, NY: Cornell University Press, 2006.

Straus, Scott, and Lars Waldorf. Remaking Rwanda: State Building and Human Rights After Mass Violence. Madison: University of Wisconsin Press, 2011.

Stover, Eric, Hanny Megally, and Hania Mufti. "Bremer's 'Gordian Knot': Transitional Justice and the US Occupation of Iraq." Human Rights Quarterly 27, no. 3 (2005): 830-57.

Teitel, Ruti G. Transitional Justice. Oxford: Oxford University Press, 2000. "Transitional Justice Genealogy." Harvard Human Rights Journal 16 (2003): 69-94.

Thomson, Susan. "The Darker Side of Transitional Justice: The Power Dynamics Behind Rwanda's Gacaca Courts." Africa 81, no. 3 (2011): 373-90.

—. Whispering Truth to Power: Everyday Resistance to Reconciliation in Postgenocide Rwanda. Madison: University of Wisconsin Press, 2013.

Tilly, Charles. From Mobilization to Revolution. New York: McGraw-Hill, 1978.

—. "War Making and State Making as Organized Crime." In Bringing the State Back In, edited by Peter B. Evans, Dietrich Rueschemeyer, and Theda Skocpol, 169-91. Cambridge: Cambridge University Press, 1985.

United Nations. "Report on the Situation of Human Rights in Rwanda." E/CN.4/1996/68. New York: United Nations, 1996.

Waldorf, Lars. "Rwanda's Failing Experiment in Restorative Justice." In Handbook of Restorative Justice: A Global Perspective, edited by Dennis Sullivan and Larry Tifft, 422-34. New York: Routledge, 2006.

Weber, Max. Economy and Society: An Outline of Interpretive Sociology. Berkeley: University of California Press, [1922] 1978.

\section{STATUTES CITED}

ICTR Statute. 1994. http://www.ohchr.org/EN/ProfessionalInterest/Pages/StatuteInternational CriminalTribunalForRwanda.aspx.

Organic Law n ${ }^{\circ}$ 13/2008 of May 19, 2008, Rwanda. 